\title{
Dramatic Change in Citrus tristeza virus Populations in the Dominican Republic
}

Luis A. Matos, Citrus Research and Education Center, University of Florida, Lake Alfred, FL 33850, and Instituto Dominicano de Investigaciones Agropecuarias y Forestales (IDIAF), Santo Domingo, Dominican Republic; Mark E. Hilf, United States Department of Agriculture-Agricultural Research Service USHRL, Fort Pierce, FL 34945; Xiomara A. Cayetano, IDIAF, Dominican Republic; Andrea O. Feliz, IDIAF and Departamento de Sanidad Vegetal-Ministerio de Agricultura, Santo Domingo, Dominican Republic; and Scott J. Harper and Svetlana Y. Folimonova, Citrus Research and Education Center, University of Florida, Lake Alfred, FL 33850

\begin{abstract}
Matos, L. A., Hilf, M. E., Cayetano, X. A., Feliz, A. O., Harper, S. J., and Folimonova, S. Y. 2013. Dramatic change in Citrus tristeza virus populations in the Dominican Republic. Plant Dis. 97:339-345.

Citrus tristeza virus (CTV) is the most destructive viral pathogen of citrus and has been an important concern for the citrus industry in the Dominican Republic. Earlier studies documented widespread distribution of mild isolates of the T30 genotype, which caused no disease in the infected trees, and a low incidence of isolates of the VT and T3 genotypes, which were associated with economically damaging decline and stem-pitting symptoms in sweet orange and Persian lime, the two major citrus varieties grown in the Dominican Republic. In light of the dramatic increase in the number of severely diseased citrus trees

ulations of CTV have changed, we examined the CTV pathosystem in the Dominican Republic to assess the dynamics of virus populations. In this work, we characterized the molecular composition of $163 \mathrm{CTV}$ isolates from different citrus-growing regions. Our data demonstrate a dramatic change in CTV populations, with the VT genotype now widely disseminated throughout the different regions and with the presence of two new virus genotypes, T36 and RB. Multiple infections of trees resulted in development of complex virus populations composed of different genotypes.
\end{abstract} throughout the country over the last decade, suggesting that field pop-
Citrus tristeza virus (CTV) is the most destructive viral pathogen of citrus (34). It is also the largest member of the Closteroviridae family, which contains viruses with mono-, bi-, and tripartite genomes transmitted by a range of insect vectors, including aphids, whiteflies, and mealybugs $(2,5,10,11,23)$. CTV has long flexuous virions (2,000 by 10 to $12 \mathrm{~nm})$ encapsidated by two coat proteins (CPs) and a single-stranded RNA genome of approximately 19.3 $\mathrm{kb}$. The RNA genome of CTV contains 12 open reading frames (ORFs) (24,35). ORFs $1 \mathrm{a}$ and $1 \mathrm{~b}$ are expressed from the genomic RNA and encode polyproteins required for virus replication. Ten $3^{\prime}$ end ORFs are expressed by $3^{\prime}$ co-terminal subgenomic RNAs $(21,25)$ and encode the following proteins: major (CP) and minor (CPm) CPs, p65 (HSP70 homolog), and p61 that are involved in assembly of virions (45); a hydrophobic $\mathrm{p} 6$ protein with a proposed role in virus movement $(11,49)$; p20 and p23, which, along with the CP, were shown to be suppressors of RNA silencing in Nicotiana benthamiana (29); and p33, p13, and p18, which function in extending the virus host range (50).

CTV has numerous isolates with distinctive biological and genetic characteristics, which can be classified into six major CTV genotype groups or strains: T3, T30, T36, VT, T68, and RB, with some isolates unclassified $(13,19,22,26,38,42,43)$. Strains are defined as phylogenetically distinct lineages of CTV based upon analysis of nucleotide sequences of the 1a ORF $(13,22)$. This region of the genome shows high genetic diversity between CTV variants, with levels of sequence identity of 72.3 to $90.3 \%$ $(19,22,26,28,32,42,43)$. This compares with a range of 89 to $94.8 \%$ identity found in more conserved $3^{\prime}$ half regions of the genomes of isolates from different CTV strains. Each strain is composed of isolates with minor sequence divergence, generally less than $5 \%$

Corresponding author: S. Y. Folimonova, E-mail: svetlana@ufl.edu

Accepted for publication 5 September 2012.

http://dx.doi.org/10.1094/PDIS-05-12-0421-RE

(C) 2013 The American Phytopathological Society throughout the entire genome $(19,22,34)$. At the same time, isolates of a strain may have significant variations in symptoms and symptom severity. Remarkably, field trees harbor complex populations of CTV, which are often composed of mixtures of different genotypes and recombinants between these genotypes $(17,26,28,30,37$, 43,54,55).

The host range of CTV is limited to citrus and citrus relatives in which the virus infects only phloem-associated cells. CTV infection is associated with two devastating diseases of citrus, which have had a major impact on global citrus production $(4,34)$. Depending on the virus isolate and the variety-rootstock combination, CTV can cause decline, which is a graft incompatibility, or stem pitting. The first disease results in a death of sweet orange (Citrus sinensis (L.) Osbeck), mandarin (C. reticulata Blanco), or grapefruit $(C$. paradisi Macfadyen) trees grafted on sour orange $(C$. aurantium L.) rootstocks. During the last century, decline-causing CTV isolates caused severe epidemics in many different citrusgrowing areas worldwide, which resulted in the loss of almost 100 million trees propagated on the popular sour orange (34). Isolates of strains T36 or VT have been found associated with the decline syndrome. Stem pitting, often caused by some of the severe isolates of strains VT, T3, or T68, substantially reduces growth and fruit quality of grapefruit, sweet orange, and lime (C. aurantifolia (Christm.) Swingle) trees regardless of the rootstock used, thus limiting a number of varieties that can be grown commercially where these strains are present $(14,22,34,40)$.

CTV dissemination to new regions occurs mainly via movement of infected plants or propagation of infected budwood followed by further local spread by several aphid species (34). The first large dispersal of the virus from its presumed origin in South East Asia into new regions resulted from an active movement of different citrus varieties at the end of 19th century (34). Since then, multiple examples of inadvertent introduction of exotic isolates of CTV into different citrus-producing countries, which resulted from the international movement of citrus varieties, have been documented (34). The detection in 2000 in California of exotic severe stempitting CTV isolates in mandarin plantings, which originated from illegal budwood imports (M. Polek and R. Yokomi, personal com- 
munication), and the discovery of VT isolates in commercial citrus in Florida $(20,46)$ represent recent examples. Because the introduction of aggressive virus isolates from outside sources or their emergence from unrecognized existing infections appears to be a continuing threat to the citrus industries in many different countries, proactive identification and eradication of the infected trees as well as the development of means to protect new plantings against aggressive isolates become critical for virus suppression.

CTV has been a major concern for the citrus industry in the Dominican Republic, which encompasses more than 30,000 hectares. Sweet orange varieties represent about $70 \%$ of all plantings, followed by Persian lime, Mexican lime, mandarin, and grapefruit. The virus presence in the commercial plantations was initially reported in 1990 but the infected trees did not show obvious disease symptoms (27). Surveys made during 1990 to 1992 indicated that CTV was not yet widely spread (7). In 1992, the brown citrus aphid (Toxoptera citricidus Kirk.) was found in the Central region of the country. With the brown citrus aphid being the most efficient insect vector of CTV $(34,38)$, its presence apparently provided favorable conditions for dispersal of the virus into different areas $(1,12)$. From 1992 to 1995 , repeated surveys showed a rapid diffusion of CTV into commercial citrus plantings (15). At that time, none of the virus-containing samples reacted with the monoclonal antibody MCA-13 (36), which indicated that the endemic isolates only had the T30 genotype, and no visible evidence of quick decline or stem pitting was found (15). By 1995, the incidence of the T30 isolates of CTV has risen to almost 50 to $90 \%$ in many citrusgrowing areas (15).

The first occurrence of severe isolates of CTV leading to decline or stem pitting in citrus trees in the Dominican Republic was reported in 1996 in Valencia sweet orange in Hato Mayor, one of the major commercial production areas in the East region of the country (16; Fig. 1A). One year later, Persian lime trees with typical CTV-related vein-clearing and stem-pitting symptoms were found in the Monte Plata area in the Central region (16; Fig. 1A). Samples collected from the symptomatic trees in both regions reacted with the MCA-13 antibody, indicating dispersion of isolates new to the country. Analysis of the genotype composition of those isolates revealed the presence of the VT and T3 genotypes (16). Although the trees carrying exotic isolates were detected in two geographically distant areas, subsequent surveys showed that their incidence was very low, ranging between 2 to $5.4 \%$ in the East and 0.5 to $1.75 \%$ in the Central regions in 1997 (16). Since then, the increasing occurrence of CTV-associated decline of sweet orange trees grafted on sour orange rootstock and development of severe stempitting symptoms in a large proportion of sweet orange and Persian lime trees in many agricultural regions throughout the country were observed. During the following years, a great number of sweet orange trees grown on sour orange rootstock have declined, and those were replaced with sweet orange propagated on declineresistant rootstocks (31). Although new replantings were done using MCA-13-negative budwood sources, many trees developed severe stem-pitting symptoms within a few years and, over the last decade, stem pitting became the major economically damaging disease of citrus in the country (31). A significant increase in a number of the diseased trees correlated with a change in the serological characteristics of the CTV isolates. A great majority of the virus samples collected from field citrus trees in the recent years showed reaction with the MCA-13 antibody (31). Altogether, those observations suggested that field populations of CTV were changing.

The CTV pathosystem in the Dominican Republic represents a unique opportunity to examine the evolution of virus populations within a defined geographical area. As discussed above, the distribution and genotype composition of CTV isolates in the country has been examined previously at different time points. The data of earlier studies provided a possibility to assess changes in the composition of virus populations over a period of time. To evaluate the current population complexity of CTV in the Dominican Republic, we conducted a comprehensive examination of samples collected in different commercial citrus production areas. Using a reversetranscription polymerase chain reaction (RT-PCR) assays with genotype-specific molecular markers coupled with sequencing analysis, we characterized molecular composition of 163 CTV isolates collected from several locations within the country. Overall, our data demonstrate a dramatic change in the CTV populations that occurred within the last 10 years in the Dominican Republic, which is characterized by increased dissemination of the previously found genotypes to new regions, with the VT genotype now widely spread throughout the country, the presence of two new virus genotypes, and the predominance of complex virus populations composed of different genotypes.
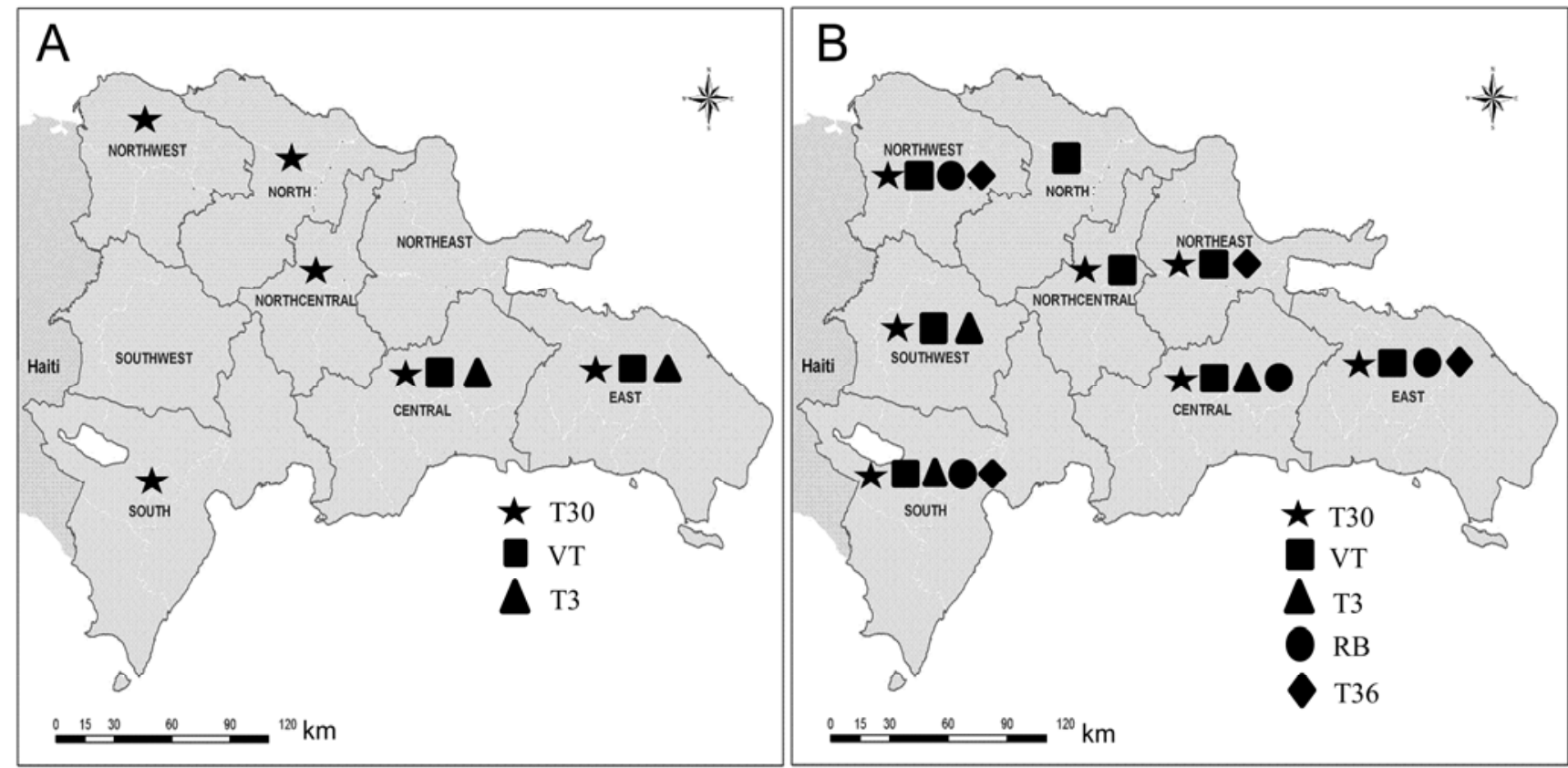

Fig. 1. Distribution of Citrus tristeza virus (CTV) genotypes in eight citrus-growing regions in the Dominican Republic. A, Virus distribution according to the earlier study conducted by Garnsey et al. (16); Northeast and Southwest regions were not sampled because no commercial citrus plantings were developed in those regions at that time. B, Current distribution of different genotypes of CTV based on the data presented in this work. Different virus genotypes are shown by symbols as indicated on the figure. 


\section{Materials and Methods}

Sample collection. Samples for RT-PCR analysis were petioles from young leaves or pedicels from young fruit, which were collected from individual field trees. Six petioles or three pedicels were collected from each tree. Trees were sampled regardless of their outward appearance but many trees that were sampled expressed symptoms of severe stem pitting. In total, 192 samples were collected in 38 citrus farms from 24 provinces in the eight agricultural regions in the Dominican Republic (Fig. 1).

Analysis of virus population accumulated in citrus trees. To examine CTV population in citrus trees, $150 \mathrm{mg}$ of tissue was ground with liquid nitrogen, and total RNA was extracted with the Trizol Reagent (Invitrogen) according to the procedure of the manufacturer. Total RNA was subjected to RT-PCR using the Titan One Tube RT-PCR System (Roche) according to the manufacturer's protocol. A universal CTV CP primer set was used first to detect the presence of the virus, followed by genotype-specific primers complimentary to sequences within the ORFs $1 \mathrm{a}-1 \mathrm{~b}$ of the VT, T30, T3, T68, T36, or RB genomes to identify individual genotypes within each CTV-positive sample (3,19,22,24,32; M. E. Hilf and S. J. Harper, personal communication; Table 1). Each isolate was analyzed using 18 marker primer sets designed to specifically amplify distinct genomic regions within the ORFs 1a

Table 1. Sequences of marker primers used for characterization of Citrus tristeza virus (CTV) genotypes from the Dominican Republic

\begin{tabular}{|c|c|c|c|}
\hline Target $^{\mathbf{a}}$ & Position & $5^{\prime}-3^{\prime}$ & Size (bp) \\
\hline \multirow[t]{2}{*}{$\mathrm{CP}^{*}$} & 16,152 & (+) atg gac gac gaa aca aag aaa ttg & 671 \\
\hline & 16,823 & (-) tca acg tgt gtt gaa ttt ccc a & \\
\hline \multirow[t]{2}{*}{$\mathrm{T} 30-2$} & 792 & (+) tac ggc ttg gtg ctc tga ggc c & 843 \\
\hline & 1,635 & $(-)$ a cgc ctg cga acc gcc gac & \\
\hline \multirow{2}{*}{ Т30-K17* } & 4,848 & (+) gtt gtc gcg cct aaa gtt cgg ca & 409 \\
\hline & 5,256 & (-) tat gac atc aaa aat agc tga a & $\ldots$ \\
\hline \multirow[t]{2}{*}{ T30-POL* } & 10,772 & (+) gat gct agc gat ggt caa at & 696 \\
\hline & 11,467 & (-) ctc agc tcg ctt tct cac at & $\ldots$ \\
\hline \multirow[t]{2}{*}{ VT-3 } & 2,246 & (+) cag gtg aga att ctc cat cgt & 824 \\
\hline & 3,070 & (-) aga atc agg caa acg ccc & \\
\hline \multirow[t]{2}{*}{ VT-K17* } & 4,824 & (+) gtt gtc gcg ctt taa gtt cgg ta & 409 \\
\hline & 5,232 & (-) tac gac gtt aaa aat ggc tga a & $\ldots$ \\
\hline \multirow[t]{2}{*}{ VT-POL* } & 10,745 & (+) gac gct agc gat ggt caa gc & 695 \\
\hline & 11,440 & $(-)$ ctc ggc tcg ctt tct tac gt & $\ldots$ \\
\hline \multirow{2}{*}{ T36-3 } & 2,323 & $(+)$ ctt ctt tta act cga caa gga & 739 \\
\hline & 3,062 & (-) tgt gat tat cag gga gtt a & $\ldots$ \\
\hline \multirow[t]{2}{*}{$\mathrm{T} 36-\mathrm{K} 17 *$} & 4,865 & (+) caa cac atc aaa aat agc tag t & 409 \\
\hline & 5,273 & $(-)$ gtt ttc tcg ttt gaa gcg gaa a & \\
\hline \multirow{2}{*}{ T36-POL* } & 10,791 & (+) tga cgc taa cga cga taa cg & 717 \\
\hline & 11,508 & (-) acc ctc ggc ttg ttt tct tat $g$ & $\ldots$ \\
\hline \multirow[t]{2}{*}{ T3-2 } & 962 & (+) gtg ttg agg tcc cga gcg tc & 652 \\
\hline & 1,614 & (-) gat cga gac ggt tta gag atg & $\ldots$ \\
\hline \multirow{2}{*}{$\mathrm{T} 3-\mathrm{K} 17 *$} & 4,871 & (+) gtt atc acg cct aaa gtt tgg t & 409 \\
\hline & 5,279 & (-) cat gac atc gaa gat agc cga a & \\
\hline \multirow[t]{2}{*}{ T3-5 } & 6,133 & (+) tcc tt gcc atc aat tgt atc ac & 397 \\
\hline & 6,530 & $(-)$ cac gtg gaa agt tcc acg acg & $\ldots$ \\
\hline \multirow[t]{2}{*}{ RB-1404 } & 1,404 & $(+)$ aca gtg ggt gca ttt aag gct tat & 1,731 \\
\hline & 3,135 & (-) gag cat tac ttg ctg gtt ctc act & $\ldots$ \\
\hline \multirow[t]{2}{*}{ RB-K17 } & 4,847 & (+) gtt ttc acg tct gaa acg aaa g & 409 \\
\hline & 5,256 & (-) cca aca cat caa aaa tag cct g & \\
\hline \multirow[t]{2}{*}{ RB-7424 } & 7,424 & (+) ggt tcg agg tca tgc tag gg & 721 \\
\hline & 8,145 & $(-)$ gaa cca acc cat cat tgc ag & $\ldots$ \\
\hline \multirow[t]{2}{*}{ T68-1771 } & 1,771 & (+) cga gta taa acc gga agt tcc & 743 \\
\hline & 2,415 & $(-)$ aca gac gac cca aaa cta tgc & $\ldots$ \\
\hline \multirow[t]{2}{*}{ T68-K17 } & 4,840 & $(+)$ cet ttt cgc agc taa agt gca gc & 571 \\
\hline & 5,411 & $(-)$ ctt atc aaa ggc tt agc act t & $\ldots$ \\
\hline \multirow[t]{2}{*}{ T68-5716 } & 5,716 & (+) gga gtt aac tag tgg tgg tag & 1,304 \\
\hline & 7,020 & (-) ctt cat act aaa cgc gtt acg & $\ldots$ \\
\hline
\end{tabular}

a Primers were generated against an alignment of extant CTV genomes $(3,19,22,24,32)$. An asterisk $(*)$ indicates primers that were described previously $(22)$. All other primers were developed in this study. Genomic positions of T68 and T3 markers were derived from pairwise alignment with the T36 genomic sequence as described (22; M. E. Hilf, personal communication).

Table 2. Occurrence of different genotypes of Citrus tristeza virus (CTV) in citrus-producing regions in the Dominican Republic determined by analysis with genotype-specific primers

\begin{tabular}{|c|c|c|c|c|c|c|c|}
\hline \multirow[b]{2}{*}{ Regions } & \multicolumn{2}{|c|}{ Number of samples } & \multicolumn{5}{|c|}{ Frequency of CTV genotypes $(\%)^{\mathrm{a}}$} \\
\hline & Collected & CTV positive & T30 & VT & T3 & T36 & RB \\
\hline Central & 35 & 28 & $75.0(21 / 28)$ & $100.0(28 / 28)$ & $3.6(1 / 28)$ & $0.0(0 / 28)$ & $7.1(2 / 28)$ \\
\hline East & 42 & 36 & $86.1(31 / 36)$ & $97.2(35 / 36)$ & $0.0(0 / 36)$ & $2.8(1 / 36)$ & $5.6(2 / 36)$ \\
\hline Northeast & 30 & 27 & $63.0(17 / 27)$ & $96.3(26 / 27)$ & $0.0(0 / 27)$ & $18.5(5 / 27)$ & $0.0(0 / 27)$ \\
\hline Southwest & 32 & 29 & $41.4(12 / 29)$ & $100.0(29 / 29)$ & $41.4(12 / 29)$ & $0.0(0 / 29)$ & $0.0(0 / 29)$ \\
\hline South & 26 & 20 & $65.0(13 / 20)$ & $80.0(16 / 20)$ & $5.0(1 / 20)$ & $5.0(1 / 20)$ & $15.0(3 / 20)$ \\
\hline Northwest & 15 & 15 & $100.0(15 / 15)$ & $93.3(14 / 15)$ & $0.0(0 / 15)$ & $6.7(1 / 15)$ & $6.7(1 / 15)$ \\
\hline North & 8 & 4 & $0.0(0 / 4)$ & $100.0(4 / 4)$ & $0.0(0 / 4)$ & $0.0(0 / 4)$ & $0.0(0 / 4)$ \\
\hline Northcentral & 4 & 4 & $75.0(3 / 4)$ & $100.0(4 / 4)$ & $0.0(0 / 4)$ & $0.0(0 / 4)$ & $0.0(0 / 4)$ \\
\hline Total & 192 & 163 & $68.7(112 / 163)$ & $95.7(156 / 163)$ & $8.6(14 / 163)$ & $4.9(8 / 163)$ & $4.9(8 / 163)$ \\
\hline
\end{tabular}

a Percentage of CTV-positive samples in which a particular virus genotype was detected. Numbers in parentheses indicate number of samples containing a particular genotype out of a total number of CTV-positive samples collected in a region. 
or $1 \mathrm{~b}$ of the above six genotypes of the virus (Table 1). Reaction products were analyzed by electrophoresis in $1 \%$ agarose gels containing ethidium bromide at $200 \mathrm{ng}$ per $\mathrm{ml}$.

A subset of tissue samples was also analyzed using viral immunocapture procedure with CTV polyclonal IgG as described in previous publications $(16,22)$, followed by RT-PCR amplification with genotype-specific primers, which yielded equivalent results compared with amplification using total RNA extracted according to the protocol above.

Cloning and sequencing analysis. Selected RT-PCR products amplified using primers corresponding to the genomes of the VT, T30, T3, T36, or RB genotypes as indicated above (reactions carried out using the T68-specific primers did not yield any products) were cloned into pGEM-T vector (Promega Corp.) according to the manufacturer's instructions and were submitted for sequencing (Macrogen USA) in both sense and antisense directions using vector-specific M13 primers. At least two clones for each PCR product were sequenced. Sequence chromatograms were checked for errors, and the sense and antisense sequences for each fragment were assembled. Completed sequences were deposited in the National Center for Biotechnology Information (NCBI) GenBank database (accession numbers JQ281780 to JQ281788) and compared with the GenBank database using the BLASTn network service in the NCBI.

Phylogenetic analysis. Using ClustalX 1.83 (51), the assembled fragments were aligned against a series of CTV sequences representative of each of the major genotypes: T30 (3); T385 (53); T36 (24); VT (32); NZ-B18 and NZ-M16 (18); NZRB-M12, NZRBM17, and NZRB-G90 (19); B165 (41); HA18-1 (33); and T3, B370, and B59 (22) from around the globe. Neighbor-joining phylogenies (44) were created using the Tamura-Nei model (47) with MEGA 5.0 (48). Bootstrap values were generated from 1,000 replicates.

\section{Results}

Incidence of CTV in citrus-producing regions of the Dominican Republic. In order to analyze the dynamics of CTV populations in the Dominican Republic, we first examined what proportion of samples obtained from different citrus plantations throughout the country contained the virus. Tissue samples were collected in the citrus-producing areas in the eight agricultural

Table 3. Marker profiles of Citrus tristeza virus (CTV) genotypes

\begin{tabular}{lcccccc}
\hline & \multicolumn{5}{c}{ CTV genotype } \\
\cline { 2 - 7 } Marker & T30 & VT & T36 & T3 & RB & T68 \\
\hline CP & 1 & 1 & 1 & 1 & 1 & 1 \\
T30-2 & 1 & 1 & 0 & 0 & 0 & 0 \\
T30-K17 & 1 & 0 & 0 & 0 & 0 & 0 \\
T30-POL & 1 & 0 & 0 & 0 & 0 & 0 \\
VT-3 & 0 & 1 & 0 & 0 & 0 & 0 \\
VT-K17 & 0 & 1 & 0 & 0 & 0 & 0 \\
VT-POL & 0 & 1 & 0 & 1 & 0 & 1 \\
T36-3 & 0 & 0 & 1 & 0 & 0 & 0 \\
T36-K17 & 0 & 0 & 1 & 0 & 0 & 0 \\
T36-POL & 0 & 0 & 1 & 0 & 0 & 0 \\
T3-2 & 0 & 0 & 0 & 1 & 0 & 0 \\
T3-K17 & 0 & 0 & 0 & 1 & 0 & 0 \\
T3-5 & 0 & 0 & 0 & 1 & 0 & 0 \\
RB-1404 & 0 & 0 & 0 & 0 & 1 & 0 \\
RB-K17 & 0 & 0 & 0 & 0 & 1 & 0 \\
RB-7424 & 0 & 0 & 0 & 0 & 1 & 0 \\
T68-1771 & 0 & 0 & 0 & 0 & 0 & 1 \\
T68-K17 & 0 & 0 & 0 & 0 & 0 & 1 \\
T68-5716 & 0 & 0 & 0 & 0 & 0 & 1 \\
\hline
\end{tabular}

a Numbers: 1 indicates marker amplification and 0 indicates no amplification. Marker patterns resulted from reverse-transcription polymerase chain reaction amplification using RNA extracts from designated reference isolates, each representing a particular genotype: T30, T3, T36, T68, and 701 (VT genotype) from Florida $(3,13,22,24 ;$ Z. Xiong and S. J. Harper, personal communication). The expected marker profile for the RB genotype is presented according to the previous studies (19; S. J. Harper, personal communication). regions (Fig. 1). In total, 192 samples were collected from trees with various degrees of symptoms, ranging from none or very mild symptoms to more advanced stages of stem pitting. The samples were analyzed by RT-PCR using primers derived from a region within the CP ORF (Table 1) that is highly conserved in different CTV genotypes and, thus, these primers are expected to amplify from a wide range of CTV genotypes. CTV was detected in 163 of $192(84.9 \%)$ samples from all eight agricultural regions (Table 2). The incidence of virus appeared to be high in all those regions, ranging from 80 to $100 \%$ in most areas (Table 2).

Distribution of CTV genotypes in the different citrus-growing regions in the Dominican Republic. Earlier genetic marker studies of CTV populations in the Dominican Republic detected three distinct genotypes: T30, VT, and T3 $(16,22)$. The T30 genotype was widely spread in six of eight citrus-growing regions, whereas the VT and T3 were detected only in the Central and East regions in a low proportion of trees (16; Fig. 1A). To assess possible changes in the structure of CTV populations in the Dominican Republic, we conducted RT-PCR analyses of collected isolates using genotype-specific marker primers that selectively amplify sequences of particular genotypes of the virus and, thus, allow discrimination between different genotypes and identification of individual components of virus isolates (Table 1). Presence of a genotype in the isolate was determined based on the similarity of the marker pattern to the marker profiles of the reference isolates of the T30, VT, T36, T3, RB, and T68 genotypes (Table 3) and further confirmed by following sequencing analysis.

Analysis of 163 CTV isolates collected from different citrusgrowing regions demonstrated wide distribution of the T30 genotype, which correlated with the previous observations. This genotype was detected in $68.7 \%$ (112 of 163) of CTV-positive samples from seven of the eight regions, with new findings in the Southwest and Northeast regions (Table 2; Fig. 1B). The T30 genotype was not detected in samples from the North region, where it was detected in the original study, likely due to a small number of samples collected in that area. Remarkably, in addition to previously widely distributed T30 genotype, the VT genotype has spread to all of the citrus-producing areas and was the most prevalent genotype of CTV throughout the country, detected in $95.7 \%$ (156 of 163) of the CTV-positive samples (Table 2; Fig. 1B). The occurrence of the VT genotype appeared to be similar in different regions of the country, ranging between 80 and $100 \%$, which indicated highly effective spread of this genotype from the initial introduction site (Table 2). Among the VT-containing samples, 26.9\% (42 of 156) were infected singly by this genotype, whereas most of the samples were found co-infected with T30: $56.4 \%$ (88 of 156) of those samples had only the VT and T30 genotypes and 10.9\% (17 of 156) contained those genotypes along with some additional genotypes of the virus (Table 4). Interestingly, the T3 genotype, which has been also found in the two main citrus-growing regions (Central and East regions) during the previous surveys, did not appear to spread as well as the above genotype. The T3 was detected only in the Central, South, and Southwest regions in a low proportion $(8.6 \%, 14$ of 163$)$ of samples in mixed infections with either T30 ( 1 of 14), VT (6 of 14), or both T30 and VT (7 of 14) genotypes (Tables 2 and 4; Fig. 1).

Further examination of samples revealed the presence of two genotypes that have not been reported in the Dominican Republic: $\mathrm{RB}$ and T36 (Table 2). The RB and T36 genotypes were each present in four of the eight regions at a low incidence (4.9\%) and were found in mixed infections with the VT and T30 genotypes (Tables 2 and 4; Fig. 1B).

Phylogenetic analysis. Neighbor-joining analysis indicated that sequences amplified with primers specific to the K17 region within ORF 1a of the indicated genotype (Table 1) clustered with representative and the type sequences of that genotype (Fig. 2). These results corroborated the marker data and confirmed the presence of the T36 and RB genotypes as well as the previously reported the VT, T3, and T30 genotypes. Results of the BLASTn analysis of the DR-65-RB (JQ281780) and DR-67-RB (JQ281781) K17 se- 
quences showed approximately $98 \%$ identity to sequences of recognized RB isolate NZRB-M12 from New Zealand (FJ525431) (Fig. 2). The DR-48-T36 (JQ281787) and DR-80-T36 (JQ281788) $\mathrm{K} 17$ sequences had 96.6 to $100 \%$ identity with the type T36 isolate from Florida (U16304). The DR-26-VT (JQ281782) and DR-52VT (JQ281783) K17 sequences were 98\% identical to corresponding sequence of the Israeli VT isolate (U56902). The sequence identities of the DR-13-T3 (JQ281785) and DR-32-T3 (JQ281786) K17 regions was 95.2 to $99.6 \%$ to T3 isolates, with the DR-13-T3 showing $99.6 \%$ similarity to Florida T3 sequence (AY756314). The DR-35-T30 (JQ281784) was identical (100\%) to the type T30 isolate from Florida (AF260651).

CTV genotypes in different citrus varieties. Samples collected during our study were mainly sweet orange, Persian lime, and Mexican lime, which allowed us to compare the incidence of each CTV genotype among these economically important citrus varie- ties. The VT genotype was the most prevalent in all of the varieties tested and was found with a similar incidence of 92.2 to $100 \%$, followed by the T30 genotype, which was detected in 82.8, 63.1, and $66.7 \%$ of CTV-positive samples from sweet orange, Persian lime, and Mexican lime, respectively. The frequencies of the RB and T36 genotypes varied more significantly between citrus varieties. The presence of the RB genotype ranged from $1.0 \%$ in virus samples from Persian lime to $8.6 \%$ in sweet orange and $20 \%$ in Mexican lime virus-containing samples. The T36 genotype was detected in $5.8 \%$ of Persian lime, $2.9 \%$ of sweet orange, and $6.7 \%$ of Mexican lime CTV-positive samples. The T3 genotype was found only in Persian lime (in $13.6 \%$ of virus-positive samples).

\section{Discussion}

The results of this study provide an example of rapid and significant changes in the distribution and composition of virus popula-

Table 4. Summary of genotype combinations found in the Dominican Republic ${ }^{\text {a }}$

\begin{tabular}{|c|c|c|c|c|c|c|c|c|c|c|c|c|c|}
\hline Region & T30 & VT & $\begin{array}{l}\text { T3+ } \\
\text { T30 }\end{array}$ & $\begin{array}{c}\text { T3+ } \\
\text { T30+ } \\
\text { VT } \\
\end{array}$ & $\begin{array}{c}\text { T3+ } \\
\text { VT }\end{array}$ & $\begin{array}{c}\text { T30+ } \\
\text { T36 }\end{array}$ & $\begin{array}{c}\text { T30+ } \\
\text { T36+ } \\
\text { VT }\end{array}$ & $\begin{array}{c}\text { T30+ } \\
\text { T36+ } \\
\text { VT +RB }\end{array}$ & $\begin{array}{c}\text { T30+ } \\
\text { VT }\end{array}$ & $\begin{array}{l}\text { T30+ } \\
\text { VT+ } \\
\text { RB }\end{array}$ & $\begin{array}{c}\text { T36+ } \\
\text { VT+ } \\
\text { RB }\end{array}$ & $\begin{array}{c}\text { VT+ } \\
\text { RB }\end{array}$ & Total \\
\hline Central & 0 & 7 & 0 & 1 & 0 & 0 & 0 & 0 & 18 & 2 & 0 & 0 & 28 \\
\hline East & 1 & 4 & 0 & 0 & 0 & 0 & 0 & 0 & 29 & 1 & 1 & 0 & 36 \\
\hline Northeast & 1 & 10 & 0 & 0 & 0 & 0 & 5 & 0 & 11 & 0 & 0 & 0 & 27 \\
\hline Southwest & 0 & 11 & 0 & 6 & 6 & 0 & 0 & 0 & 6 & 0 & 0 & 0 & 29 \\
\hline South & 3 & 5 & 1 & 0 & 0 & 0 & 0 & 1 & 8 & 0 & 0 & 2 & 20 \\
\hline Northwest & 0 & 0 & 0 & 0 & 0 & 1 & 0 & 0 & 13 & 1 & 0 & 0 & 15 \\
\hline North & 0 & 4 & 0 & 0 & 0 & 0 & 0 & 0 & 0 & 0 & 0 & 0 & 4 \\
\hline Northcentral & 0 & 1 & 0 & 0 & 0 & 0 & 0 & 0 & 3 & 0 & 0 & 0 & 4 \\
\hline Total & 5 & 42 & 1 & 7 & 6 & 1 & 5 & 1 & 88 & 4 & 1 & 2 & 163 \\
\hline
\end{tabular}

${ }^{a}$ Number of isolates.

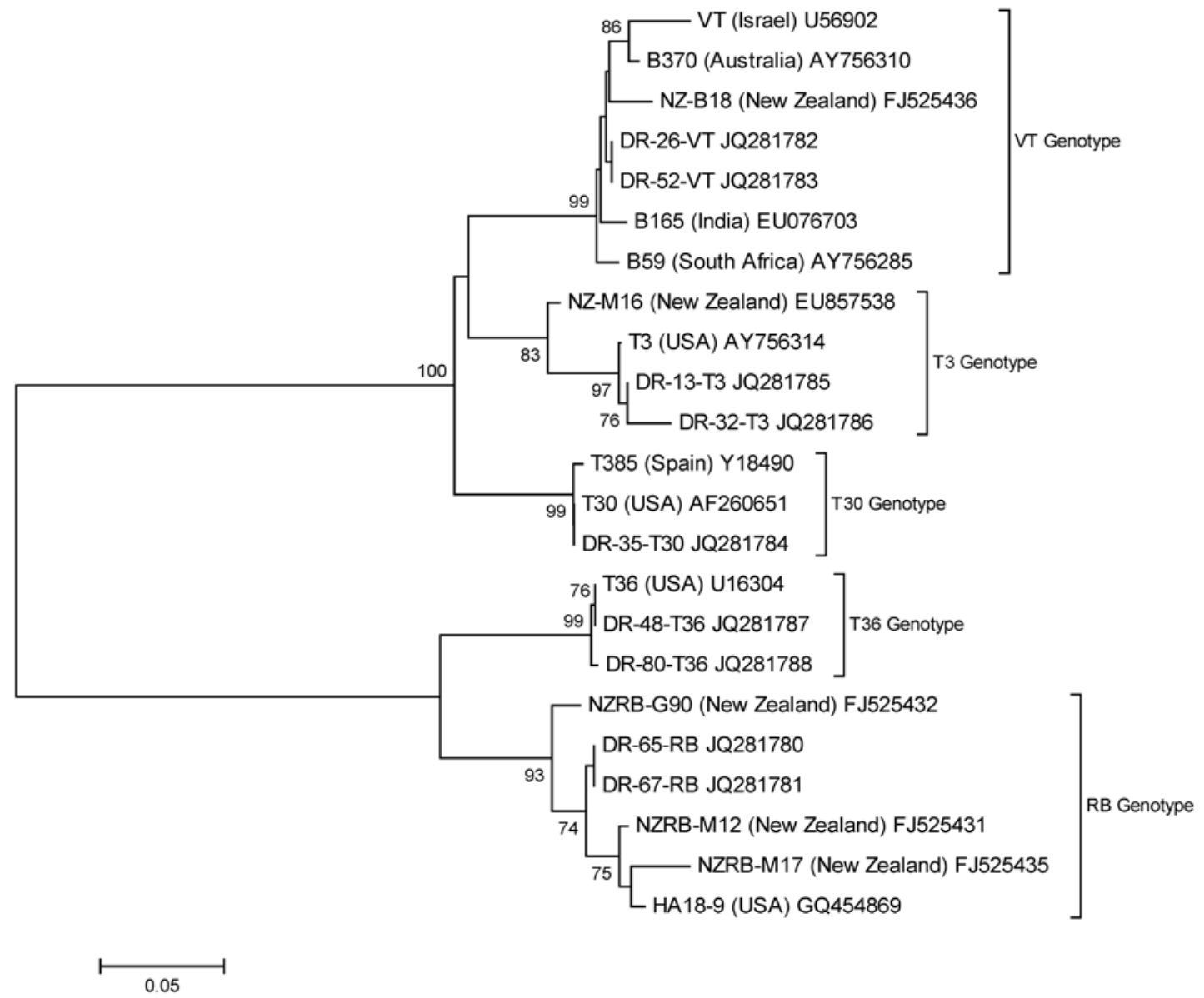

Fig. 2. Phylogenetic relationships between sequences of Citrus tristeza virus (CTV) isolates from the Dominican Republic and other CTV sequences from around the globe. Neighbor-joining analysis was applied to the K17 regions of the open reading frame 1a of selected CTV sequences from the Dominican Republic. Bootstrap values from 1,000 replicates are shown. 
tions in a defined geographical region, characterized by the increased dissemination of the existing isolates, occurrence of new distinctly different genotypes of the virus, and development of complex virus populations composed of mixtures of different genotypes. For the last 10 years, the VT isolates of CTV that were previously restricted to two areas have now spread from initial foci to all citrus-growing plantations. The level of infection by those isolates tremendously increased, reaching nearly $100 \%$ for most citrus varieties in different agricultural regions, which even exceeded the incidence of the benign T30 isolates present in the Dominican Republic for much longer. At the same time, the isolates of the T3 genotype that were discovered earlier in the same two locations as the VT isolates invaded only two other regions of the country, South and Southwest, showing relatively low rates of spread, and were associated particularly with Persian lime plantings. In addition to the previously reported virus genotypes, two new virus genotypes, T36 and RB, were detected. Both genotypes were found in a very small proportion of different varieties of citrus, suggesting that introduction of those isolates into commercial plantings could possibly be a more recent event. Alternatively, the genotypes could be present for a longer time. In particular, the sequence of the RB genotype has been determined only recently (19) and, thus, primers for the specific detection of this genotype were not available earlier. This makes it difficult to estimate how long the RB genotype has been in the Dominican Republic. For the T36, tests with the T36 genotype-specific primers were conducted earlier, yet did not yield positive results $(16,22)$, which may suggest that either the T36 was present earlier at levels below possible detection or it was introduced in the region more recently. Now these genotypes are beginning to spread into different areas.

Remarkably, it appears that the VT isolates of CTV were able to move in and spread in commercial citrus despite the fact that, prior to their introduction into the country, most citrus trees have been already infected with mild T30 isolates of the virus (15). The preexisting isolates of the T30 genotype apparently did not provide protection against the isolates of the VT genotype. The spread of the VT isolates as well as the isolates of the T3, T36, and RB genotypes resulted in formation of complex virus populations composed of various combinations of different genotypes.

Dissemination of severe isolates of CTV is an important concern for the citrus industry of the Dominican Republic, which is anticipating a significant reduction in its profitability. Taking into consideration high occurrence of severe isolates in the commercial citrus and the presence of the brown citrus aphid that could efficiently vector the virus from a tree to a tree, it would be critical to develop measures to prevent new plantings from infection with those isolates. At present, the only means to protect commercial citrus varieties from severe CTV stem pitting is cross-protection with appropriate mild CTV isolates. Development of an effective cross-protection system against aggressive isolates of CTV in the Dominican Republic could provide a means to mitigate their impact on citrus production. Selection of mild protecting isolates has enabled the efficient control of stem-pitting disease of sweet orange and lime in Brazil and Peru $(6,8)$ and grapefruit in Australia and South Africa $(9,52)$. Yet, in the past, finding protecting isolates has been empirical and, in many other cases, mild CTV isolates failed to protect or provided only limited short-term protection against severe disease (39). The results of our recent research on CTV cross-protection provide a sound recipe for finding protecting isolates. Based on understanding that sustained protection against a severe isolate of a particular CTV genotype (strain) can be achieved only by using mild isolates of the same genotype (13), the first objective for development of an effective cross-protection system is to identify the genotype of the severe isolate that needs to be controlled. Then, a mild isolate of that same genotype needs to be found. The results of the research presented here provide useful information for the first objective. It seems clear that isolates of the VT genotype widely distributed throughout the country is the cause of the economically damaging stem pitting seen in citrus groves all over the Dominican Republic. Additionally, isolates of the T3 genotype could be responsible for the stem-pitting symptoms in Persian lime plantings. Both genotypes have been known to be associated with this disease of citrus in different parts of the world (14,22). Identification of mild asymptomatic isolates of these genotypes would be a sound starting point for a program that tests the protective capabilities of these isolates. Therefore, we feel that data of this study provide the information needed to develop a management strategy for stem-pitting disease caused by CTV, which would directly benefit the industry in the Dominican Republic but which also would be an effective demonstration of how information derived from basic molecular genetics research on interactions of different virus genotypes can be used to develop an effective management program.

\section{Acknowledgments}

This research was supported by the Florida Agricultural Experiment Station. We thank the Ministry of Higher Education, Science, and Technology (MESCYT) in the Dominican Republic for providing part of the support for this study under the project number 2008-2-D1-033; Consorcio Citrícola del Este, Consorcio Cítricos Dominicanos, and Cítricos Tropicales for allowing us access to their farms for sampling; W. O. Dawson and S. M. Garnsey for insightful discussions and critical reading of the manuscript; and K. R. Sims for technical assistance in processing samples.

\section{Literature Cited}

1. Abud, A. J. 1992. Áfido vector de la Tristeza de los Cítricos en Republica Dominicana. Naturalista Postal. Herbario Universidad Autónoma de Santo Domingo, (UASD). NP 2/92.

2. Agranovsky, A. A. 1996. Principles of molecular organization, expression, and evolution of closteroviruses: over the barriers. Adv. Virus Res. 47:58 119.

3. Albiach-Martí, M. R., Mawassi, M., Gowda, S., Satyanayanana, T., Hilf, M. E., Shanker, S., Almira, E. C., Vives, M. C., López, C., Guerri, J., Flores, R., Moreno, P., Garnsey, S. M., and Dawson, W. O. 2000. Sequences of Citrus tristeza virus separated in time and space are essentially identical. J. Virol. 74:6856-6865.

4. Bar-Joseph, M., Che, X., Mawassi, M., Gowda, G., Satyanarayana, T., Ayllón, M. A., Albiach-Martí, M. R., Garnsey, S. M., and Dawson, W. O. 2002 The continuous challenge of Citrus tristeza virus molecular research. Pages 1-7 in: Proc. 15th Conf. Int. Organ. Citrus Virol. J. V. N. Duran-Vila, R. G. Milne, and J. V. da Graça, eds. International Organization of Citrus Virologists, University of California, Riverside.

5. Bar-Joseph, M., Garnsey, S. M., and Gonsalves, D. 1979. The closteroviruses: a distinct group of elongated plant viruses. Adv. Virus. Res. 25:93168.

6. Bederski, K., Roistacher, C. N., and Müller, G. W. 2005. Cross protection against the severe Citrus tristeza virus: stem pitting in Peru. Pages 117-126 in: Proc. 16th Conf. Int. Organ. Citrus Virol. M. E. Hilf, N. Duran-Vila, and M. A. Rocha-Peña, eds. International Organization of Citrus Virologists, University of California, Riverside.

7. Borbón, J. C., Abud, A. J., Millan, P. J., Asiático, J., and Abreu, N. 1992 Presencia de la Tristeza de los Cítricos y Toxoptera citricidus (Kilkaldy) en la República Dominicana. Pages 95-101 in: Proc. Workshop on Citrus Tristeza Virus and Toxoptera citricida in Central America: Development of Management Strategies and Use of Biotechnology for Control. R. Lastra, R. Lee, M. Rocha-Pena, C. Niblett, F. Ochoa, S. Garnsey, and R. Yokomi, eds. Maracay, Venezuela.

8. Costa, A. S., and Müller, G. W. 1980. Tristeza control by cross-protection: A U. S.-Brazil cooperative success. Plant Dis. 64:538-541.

9. Cox, J. E., Fraser, L. R., and Broadbent, P. 1976. Grapefruit stem pittingfield protection by mild strains. Pages 64-70 in: Proc. 7th Conf. Int. Organ. Citrus Virol. E. C. Calavan, ed. International Organization of Citrus Virologists, University of California, Riverside.

10. Dolja, V. V, Karasev, A. V., and Koonin, E. V. 1994. Molecular biology and evolution of closteroviruses: sophisticated build-up of large RNA genomes. Annu. Rev. Phytopathol. 32:261-285.

11. Dolja, V. V., Kreuze, J. F., and Valkonen, J. P. T. 2006. Comparative and functional genomics of closteroviruses. Virus Res. 117:38-51.

12. Etienne, J., Abud, A. J., Reyes M. Y., and Díaz, F. 1992. Toxoptera citricida (Homoptera-Aphididae) en la República Dominicana: una amenaza para las plantaciones de cítricos. In: XXVIII Reunión Anual de la Sociedad Caribeña de Cultivos Alimenticios, Santo Domingo, República Dominicana.

13. Folimonova, S. Y., Robertson, C. J., Shilts, T., Folimonov, A. S., Hilf, M. E., Garnsey, S. M., and Dawson, W. O. 2010. Infection with strains of Citrus tristeza virus does not exclude superinfection by other strains of the virus. J. Virol. 84:1314-1325.

14. Garnsey, S. M., Civerolo, E. L., Gumpf, D. J., Paul, C., Hilf, M. E., Lee, R. F., Brlansky, R. H., Yokomi, R. K., and Hartung, J. S. 2005. Biological characterization of an international collection of Citrus tristeza virus (CTV) isolates. Pages 75-93 in: Proc. 16th Conf. Int. Organ. Citrus Virol. M. E. Hilf, N. Duran-Vila, and M. A. Rocha-Peña, eds. International Organization of 
Citrus Virologists, University of California, Riverside.

15. Garnsey, S. M., Gottwald, T. R., and Borbón, J. C. 1996. Rapid dissemination of mild isolates of citrus tristeza virus following introduction of Toxoptera citricida in the Dominican Republic. Pages 92-103 in: Proc. 13th Conf. Int. Organ. Citrus Virol. J. V. da Graça, P. Moreno, and R. K. Yokomi, eds. International Organization of Citrus Virologists, University of California, Riverside.

16. Garnsey, S. M., Gottwald, T. R., Hilf, M. E., Matos, L., and Borbón, J. C. 2000. Emergence and spread of severe strains of Citrus tristeza virus in the Dominican Republic. Pages 57-68 in: Proc. 14th Conf. Int. Org. Citrus Virol. J. V. da Graça, R. F. Lee, and R. K. Yokomi, eds. International Organization of Citrus Virologists, University of California, Riverside.

17. Grant, T. J., and Higgins, R. P. 1957. Occurrence of mixtures of tristeza virus strains in citrus. Phytopathology 47:305-317.

18. Harper, S. J., Dawson, T. E., and Pearson, M. N. 2009. Complete genome sequences of two distinct and diverse Citrus tristeza virus isolates from New Zealand. Arch. Virol. 154:1505-1510.

19. Harper, S. J., Dawson, T. E., and Pearson, M. N. 2010. Isolates of Citrus tristeza virus that overcome Poncirus trifoliata resistance comprise a novel strain. Arch. Virol. 155:471-480.

20. Hilf, M., Garnsey, S., Robertson, C., Gowda, S., Satyanarayana, T., Irey, M., Sieburth, P., and Dawson, W. 2007. Characterization of recently introduced HLB and CTV isolates. Proc. Fla. State Hortic. Soc. 120:138-141.

21. Hilf, M. E., Karasev, A. V., Pappu, H. R., Gumpf, D. J., Niblett, C. L., and Garnsey, S. M. 1995. Characterization of citrus tristeza virus subgenomic RNAs in infected tissue. Virology 208:576-582.

22. Hilf, M. E., Mavrodieva, V. A., and Garnsey, S. M. 2005. Genetic marker analysis of a global collection of isolates of Citrus tristeza virus: characterization and distribution of CTV genotypes and association with symptoms. Phytopathology 95:909-917.

23. Karasev, A. V. 2000. Genetic diversity and evolution of closteroviruses. Annu. Rev. Phytopathol. 38:293-324.

24. Karasev, A. V., Boyko, V. P., Gowda, S., Niklaeva, O. V., Hilf, M. E., Koonin, E. V., Niblett, C. L., Cline, K., Gumpf, D. J., Lee, R. F., Garnsey, S. M., and Dawson, W. O. 1995. Complete sequence of the citrus tristeza virus RNA genome. Virology 208:511-520.

25. Karasev, A. V., Hilf, M. E., Garnsey, S. M., and Dawson, W. O. 1997. Transcriptional strategy of closteroviruses: mapping the $5^{\prime}$ termini of the citrus tristeza virus subgenomic RNAs. J. Virol. 71:6233-6236.

26. Kong, P., Rubio, L., Polek, M., and Falk, B. W. 2000. Population structure and genetic diversity within California Citrus tristeza virus (CTV) field isolates. Virus Genes 21:139-145.

27. Lee, R. F. 1990. A survey for virus and virus-like diseases of tropical fruit in the Dominican Republic. In: Report to Junta Agroempresarial de Consultoría y Coinversiones (JACC), Santo Domingo, Dominican Republic.

28. López, C., Ayllón, M. A., Navas-Castillo, J., Guerri, J., Moreno, P., and Flores, R. 1998. Molecular variability of the $5^{\prime}$ and $3^{\prime}$ terminal regions of citrus tristeza virus RNA. Phytopathology 88:685-691.

29. Lu, R., Folimonov, A. S., Shintaku, M., Li, W. X., Falk, B. W., Dawson, W. O., and Ding, S. W. 2004. Three distinct suppressors of RNA silencing encoded by a $20-\mathrm{kb}$ viral RNA genome. Proc. Natl. Acad. Sci. USA 101:15742-15747.

30. Martin, S., Sambade, A., Rubio, L., Vives, M. C., Moya, P., Guerri, J., Elena, S. F., and Moreno P. 2009. Contribution of recombination and selection to molecular evolution of Citrus tristeza virus. J. Gen. Virol. 90:15271538.

31. Matos, L. A., and Borbón, J. C. 2008. El Virus de la Tristeza de los Cítricos (CTV) en Plantaciones Comerciales y Viveros de la República Dominicana. In: Proc. 44th Annu. Meet. Caribbean Food Crops Soc. Miami, FL.

32. Mawassi, M., Mietkiewska, E., Gofman, R., Yang, G., and Bar-Joseph, M. 1996. Unusual sequence relationships between two isolates of citrus tristeza virus. J. Gen. Virol. 77:2359-2364.

33. Melzer M. J., Borth, W. B., Sether, D. M., Ferreira, S., Gonsalves, D., and $\mathrm{Hu}$, J. S. 2010. Genetic diversity and evidence for recent modular recombination in Hawaiian Citrus tristeza virus. Virus Genes 40:111-118.

34. Moreno, P., Ambros, S., Albiach-Marti, M. R., Guerri, J., and Peña, L. 2008. Citrus tristeza virus: a pathogen that changed the course of the citrus industry. Mol. Plant Pathol. 9:251-268.

35. Pappu, H. R., Karasev, A.V., Anderson, E. J., Pappu, S. S., Hilf, M. E., Febres, V. J., Eckloff, M. G., McCaffery, M., Boyko, V., Gowda, S., Dolja, V. V., Koonin, E. V., Gumpf, D. J., Cline, K. C., Garnsey, S. M., Dawson, W. O., Lee, R. F., and Niblett, C. L. 1994. Nucleotide sequence and organization of eight open reading frames of the citrus tristeza cloterovirus genome. Virology 199:35-46.

36. Permar, T. A., Garnsey, S. M., Gumpf, D. J., and Lee, R. F. 1990. A monoclonal antibody which discriminates strains of citrus tristeza virus. Phytopathology 80:224-228.

37. Raccah, B. G., Loebenstein, G., and Singer, S. 1980. Aphid-transmissibility variants of citrus tristeza virus in infected citrus trees. Phytopathology 70:89-93.

38. Rocha-Peña, M. A., Lee, R. F., Lastra, R. C., Niblett, C. L., Ochoa-Corona, F. M., Garnsey, S. M., and Yokomi. R. K. 1995. Citrus tristeza virus and its vector Toxoptera citricida. Plant Dis. 79:437-445.

39. Roistacher, C. N., and Dodds, J. A. 1993. Failure of 100 mild citrus tristeza virus isolates from California to cross protect against a challenge by severe sweet orange stem pitting isolates. Pages 100-107 in: Proc. 12th Conf. Int. Organ. Citrus Virol. P. Moreno, J. V. da Graça, and L. W. Timmer, eds International Organization of Citrus Virologists, University of California, Riverside.

40. Roistacher, C. N., and Moreno, P. 1991. The worldwide threat from destructive isolates of citrus tristeza virus. Pages 76-82, in: Proc. 8th Conf. Int. Organ. Citrus Virol. E. C. Calavan, S. M. Garnsey, and L. W. Timmer, eds. International Organization of Citrus Virologists, University of California, Riverside.

41. Roy, A., and Brlansky, R. H. 2010. Genome analysis of an orange stem pitting Citrus tristeza virus isolate reveals a novel recombinant genotype Virus Res. 151:118-130.

42. Roy, A., Manjunath, K. L., and Brlansky, R. H. 2005. Assessment of sequence diversity in the $5^{\prime}$-terminal region of Citrus tristeza virus from India. Virus Res. 113:132-142.

43. Rubio, L., Ayllon, M. A., Kong, P., Fernandez, A., Polek, M. L., Guerri, J., Moreno, P., and Falk, B. W. 2001. Genetic variation of Citrus tristeza virus isolates from California and Spain: evidence for mixed infections and recombination. J. Virol. 75:8054-8062.

44. Saitou, N., and Nei, M. 1987. The neighbour-joining method: a new method for reconstructing phylogenetic trees. Mol. Biol. Evol. 4:406-425.

45. Satyanarayana, T., Gowda, S., Mawassi M., Albiach-Marti, M. R., Ayllon, M. A., Robertson, C., Garnsey, S. M., and Dawson, W. O. 2000. Closterovirus encoded HSP70 homolog and p61 in addition to both coat proteins function in efficient virion assembly. Virology 1278:253-265.

46. Sieburth, P. J., and Nolan, K. G. 2005. Survey of stem pitting Citrus tristeza virus in commercial citrus groves in Florida. Proc. Fla. State Hortic. Soc. $118: 40-42$.

47. Tamura, K., and Nei, M. 1993. Estimation of the number of nucleotide substitutions in the control region of mitochondrial DNA in humans and chimpanzees. Mol. Biol. Evol. 10:512-526.

48. Tamura, K., Peterson, D., Peterson, N., Stecher, G., Nei, M., and Kumar, S. MEGA5: Molecular evolutionary genetics analysis using maximum likelihood, evolutionary distance, and maximum parsimony methods. Mol. Biol. Evol. In press.

49. Tatineni, S., Robertson, C. J., Garnsey, S. M., Bar-Joseph M., Gowda, S. and Dawson, W. O. 2008. Three genes of Citrus tristeza virus are dispensable for infection and movement throughout some varieties of citrus trees. Virology 376:297-307.

50. Tatineni, S., Robertson, C. J., Garnsey, S. M., and Dawson, W. O. 2011. A plant virus evolved by acquiring multiple nonconserved genes to extend its host range. Proc. Natl. Acad. Sci. USA 108:17366-17371.

51. Thompson J. D., Gibson T. J., Plewniak, F., Jeanmougin, F., and Higgins, D. G. 1997. The ClustalX window interface: flexible strategies for multiple sequence alignment aided by quality analysis tools. Nucleic Acids Res. 25, 4876-4882.

52. Van Vuuren, S. P., Collins, R. P., and da Graça, J. V. 1993. Evaluation of citrus tristeza virus isolates for cross protection of grapefruit in South Africa. Plant Dis. 77:24-28.

53. Vives, M. C., Rubio, L., López, C., Navas-Castillo, J., Albiach-Martí, M. R., Dawson, W. O., Guerri, J., Flores, R., and Moreno, P. 1999. The complete genome sequence of the major component of a mild citrus tristeza virus isoate. J. Gen. Virol. 80:811-816.

54. Vives, M. C., Rubio, L., Sambade, A., Mirkov, T. E., Moreno, P., and Guerri, J. 2005. Evidence of multiple recombination events between two RNA sequence variants within a Citrus tristeza virus isolate. Virology 331:232-237

55. Weng, Z., Barthelson, R., Gowda, S., Hilf, M. E., Dawson, W. O., Galbraith, D. W., and Xiong, Z. 2007. Persistent infection and promiscuous recombination of multiple genotypes of an RNA virus within a single host generate extensive diversity. PLOS ONE 2:e917. 